\title{
Aspects and mechanisms of low fertility in anovulatory dairy cows
}

\author{
J.E.P. Santos ${ }^{1,5}$, M.C. Wiltbank ${ }^{2}$, E.S. Ribeiro ${ }^{3}$, R.S. Bisinotto ${ }^{4}$ \\ ${ }^{1}$ Department of Animal Sciences, D. H. Barron Reproductive and Perinatal Biology Research Program, University of Florida, \\ Gainesville, FL, USA. \\ ${ }^{2}$ Department of Dairy Science, University of Wisconsin, Madison, USA. \\ ${ }^{3}$ Department of Animal Biosciences, University of Guelph, Guelph, Canada. \\ ${ }^{4}$ Department of Veterinary Population Medicine, University of Minnesota, St. Paul, MN, USA.
}

\begin{abstract}
Postpartum anovulation is a natural process that is observed in most mammals, including women. In lactating dairy cows, the interval from calving to first ovulation typically averages 4 to 5 weeks, but a substantial proportion of cows have not resumed estrous cyclicity by 60 days postpartum. Extended delay in resumption of first postpartum ovulation is known to exert long-lasting detrimental effects on fertility in dairy cows including the lack of spontaneous estrus and subsequent timely insemination postpartum, but when anovular cows have the estrous cycle synchronized for artificial insemination (AI), still pregnancy per AI is reduced and the risk of pregnancy loss increased. Many risk factors exist for extended postpartum anovulatory periods such as negative nutrient balance and diseases, and these risk factors are also known to depress fertility by themselves. A key feature in anovular cows when inseminated is that they develop the ovulatory follicle under subluteal or low concentrations of progesterone. Progesterone from the corpus luteum is pivotal for follicle development, oocyte competence, embryo growth, and endometrial function; however, many of these effects exerted by progesterone are mediated either by secretion of gonadotropins influencing follicular function and oocyte competence or by endometrial histotroph secretion influencing embryo/conceptus growth and developmental biology. Sub-optimal concentrations of progesterone during follicle growth in anovular cows affect morula and early blastocyst quality, alter conceptus gene expression and affect endometrial function increasing the synthesis of prostaglandin F2 $\alpha$. When anovular cows receive sufficient supplemental progesterone during the antral stages of development of the ovulatory follicle, then pregnancy per $\mathrm{AI}$ is reestablished and resembled that of estrous cyclic cows that developed the follicle during diestrus. Preliminary data suggest that a minimum concentration of progesterone during follicle growth is needed to optimize fertility in anovular cows, at least $2.0 \mathrm{ng} / \mathrm{ml}$.
\end{abstract}

Keyword: anovular, dairy cow, fertility, progesterone.

\section{Introduction}

Lactating dairy cattle are notorious for having less than adequate fertility as measured by suboptimal pregnancy per artificial insemination (P/AI) or by the increased pregnancy loss during the first months of gestation (Santos et al., 2004). Recent data from the United States' dairy herd indicate that P/AI has remained somewhat stable in the last 10 years, at around 33\%, whereas pregnancy rate, which is the rate at which cows become pregnant measured at 21-days intervals, increased and calving interval declined substantially (Bisinotto et al., 2014). It is thought that the improvements observed in reproductive performance in dairy herds in the United States are, in part, the result of better implemented reproductive programs. However, expressive gains in genetics for daughter fertility have also been achieved and likely P/AI will increase in the near future.

One of the impediments for proper fertility in dairy cows is delayed resumption of estrous cyclicity during the first 2 months postpartum (Santos et al., 2009). The lack of estrous cyclicity, a phenomenon also denoted as anovulation (Wiltbank et al., 2002), usually affects $25 \%$ of dairy cows by approximately 65 days in milk (Walsh et al., 2007; Santos et al., 2009). Nevertheless, some herds might have up to $40 \%$ prevalence of anovular cows by the end of the voluntary waiting period when poor peripartum health and/or poor nutritional management are in place (Walsh et al., 2007; Santos et al., 2009). Anovular cows subjected to synchronization programs for AI on estrus or timed AI usually have reduced P/AI (Santos et al., 2009; Bisinotto et al., 2010) and increased pregnancy loss compared with estrous cyclic herdmates (Santos et al., 2004; Bisinotto et al., 2010). Similar to anovular cows, those cows that develop the ovulatory follicle during the last week of growth under low concentrations of progesterone have $\mathrm{P} / \mathrm{AI}$ as low as that of anovular cows (Bisinotto et al., 2010). Such response suggests that one of the culprits for low fertility in anovular cows is likely mediated by the lack of adequate concentrations of progesterone controlling the final stages of follicle growth and/or affecting the endocrine milieu during proestrus and the uterine function during the post-ovulatory period (Cerri et al., 2011a, b; Shaham-Albalancy et al., 1997, 2001).

A strategy to counteract the negative effects of low endogenous concentrations of progesterone on fertility has been the supplementation with exogenous sources at strategic times in an attempt to improve fertility in dairy cows. Nevertheless, responses to progesterone supplementation are variable (Bisinotto and Santos, 2012; Wiltbank et al., 2012b) and oftentimes reproductive physiologists and veterinary practitioners have taken the simplistic tactic of "one approach fits 
all", which does not seem to have been very effective (Bisinotto and Santos, 2012; Wiltbank et al. 2012b). The questions that need to be asked and eventually answered are what cows require progesterone supplementation, when should progesterone be supplemented, and how much progesterone needs to be delivered to optimize establishment and maintenance of pregnancy in lactating dairy cows. Another and more long-term approach is to genetically select cows based on genomic markers linked to improved resumption of ovulation postpartum or shorter anovulatory intervals, so the prevalence of anovular cows by the end of the voluntary waiting period is reduced.

\section{The role of progesterone in controlling reproduction}

The steroid hormone progesterone is synthesized by follicles and the corpus luteum (CL; Mason and Savard, 1964), placenta (Conley and Ford, 1987), suprarenal glands (Wagner et al., 1972), and the central and peripheral nervous systems (Schumacher et $a l ., 2004)$, with that of luteal origin having the greatest importance for regulation of reproductive events in cattle. Therefore, progesterone is considered one of the key ovarian steroids regulating the estrous cycle in females. Furthermore, inadequate concentrations during distinct phases of the cycle and during pregnancy are known to impair fertility in dairy cattle.

Luteal progesterone was determined to be a key regulator of reproduction in females after the observation that the presence of CL was required for the establishment and maintenance of pregnancy (Fraenke and Cohn, 1901; Magnus, 1901; Corner and Allen, 1929). Subsequent studies described the complex mechanisms through which progesterone stimulates the secretion of nutrients and growth factors by the endometrial glands, collectively referred to as histotroph (Bazer et al., 2008). Recent studies have documented and emphasized the role of progesterone in priming the uterus for proper bovine conceptus elongation after hatching from the zona pellucida (Brandão et al., 2004; Alexopoulos et al., 2005), underlying the importance of progesterone stimulation of uterine gland secretion for successful establishment and maintenance of pregnancy in cattle.

Nevertheless, the importance of progesterone regulating reproduction in dairy cattle goes beyond its role as coordinating uterine functions during perifertilization and early embryonic periods. Progesterone plays important roles in coordinating antral follicle grew and oocyte quality through its effects on luteinizing hormone (LH) pulsatility. Lactating cows classified as having low progesterone concentrations in the week preceding spontaneous estrus had less P/AI than herdmates with high concentrations of progesterone during the same period (Folman et al., 1973). Similarly, cows in which the ovulatory follicle developed in the absence of a mature CL had reduced fertility compared with those in which follicles grow during diestrus (Bisinotto et al., 2010). These differences in fertility in cows with low compared with moderate to high concentrations of progesterone during the development of the ovulatory follicle are, in part, attributed to the permissive role of progesterone regulating follicle growth and oocyte maturation.

Progesterone exerts a regulatory effect on the hypothalamus-pituitary-gonadal axis (Clarke and Pompolo, 2005) and differences in progesterone concentrations in plasma affect follicular fluid composition (Cerri et al., 2011a), cumulus expansion and oocyte competence (Fair and Lonergan, 2012), embryo quality (Rivera et al., 2011), and uterine function during the subsequent estrous cycle (ShahamAlbalancy et al., 1997, 2001; Cerri et al., 2011a). It has been estimated that the CL of dairy cows produce large quantities of progesterone (Wiltbank et al., 2012a), but extensive catabolism by splanchnic tissues in highproducing cows results in concentrations in blood that are often considered inadequate for optimum reproduction (Wiltbank et al., 2006).

Little is known about the optimum concentrations of progesterone pre- and postinsemination that maximizes fertility in dairy cows. Numerous examples exist of failures in response to supplemental progesterone to improve fertility in cattle (Monteiro Jr et al., 2014; Wiltbank et al., 2012b; 2014). In some cases, failures occurred because the delivery systems used were either inappropriate or less than ideal from the biological point of view. In other cases, even a depression in fertility was observed with supplemental progesterone after breeding in cows receiving embryo transfer (Monteiro Jr et al., 2015).

\section{Low progesterone affects follicle and embryo quality and influences endometrial function}

Progesterone, although critical for establishment and maintenance of pregnancy, is known to exert little if any direct effect on oocytes and early embryo development (Lonergan et al., 2016). The impacts of progesterone mediating embryo quality and conceptus elongation are indirect and likely caused by a combination of effects on LH pulse frequency during follicle development and on endometrial function during the post-ovulatory period (Lonergan et al., 2016; Santos et al., 2016).

Bovine follicular cells such as those of the cumulus-oocyte complexes are responsive to progesterone and differences exist in steroidogenic activity between dominant follicles of the first compared with those of the second follicular wave (Badinga et al., 1992). First wave dominant follicles, which develop under low concentrations of systemic progesterone have high aromatase activity and concentrations of progesterone within the follicular fluid is rather high compared with those in blood plasma (Badinga et al., 1992; Cerri et al., 2001a). In fact, manipulating concentrations of progesterone in plasma did not alter the concentrations of progesterone within the follicular fluid in dairy cows (Cerri et al., 2001a). Therefore, the effects of low concentrations of progesterone in plasma on follicular function very likely are mediated by changes in LH pulsatility, and not by a direct effect of progesterone on follicular cells. 
It is well described that progesterone receptors are present in the arcuate nucleus of the hypothalamus in kiss-releasing neurons and activation of those receptors attenuates kisspeptin release which depresses gonadotropin-releasing hormone $(\mathrm{GnRH})$ pulsatility (Clarke and Pompolo, 2005). Progesterone influences the release of $\mathrm{LH}$, which can be noted by the reduction in LH pulse frequency during the luteal phase compared with the follicular phase of the estrous cycle in the sheep (Clarke, 1995) and during metestrus compared with diestrus in dairy cows (Endo et al., 2012). In fact, treatment with exogenous progesterone decreased the frequency of $\mathrm{LH}$ pulses in ovariectomized ewes (Goodman and Karsch, 1980; Goodman et al., 1982) and postpartum dairy cows (Nation et al., 2000). Nevertheless, data suggest that progesterone does not affect the amount of GnRH receptors in the pituitary gland (Schoenemann et al., 1985) and the negative feedback of progesterone on LH secretion is observed primarily at the level of the hypothalamus (Clarke and Pompolo, 2005), not the pituitary (Lane et al., 2009). Because GnRH neurons do not express progesterone receptors (Herbison et al., 1996; Skinner et al., 2001), the action of progesterone on GnRH secretion is mediated by changes in upstream release of kisspeptin. When cows are exposed to low concentrations of progesterone, LH concentrations increase, follicle growth is accelerated, and follicular composition is altered (Cerri et al., 2001a, b). Although these changes are unlikely to resemble those depicted in models for prolonged follicular dominance, the alterations in $\mathrm{LH}$ pulsatility elicited by low concentrations of progesterone likely influence oocyte quality by effects on gap junctions, protein phosphorylation and reactivation of meiosis from the diplotene stage of prophase I (Santos et al., 2016). The advancement in oocyte maturation induced by increased LH pulsatility when concentrations of progesterone are low compromises early embryonic development and conceptus elongation (Wiltbank et al., 2011).

Wiltbank et al. (2011) assigned cows to start the Ovsynch timed AI protocol on day 7 of the estrous cycle, but manipulated concentrations of progesterone such that in one treatment, cows developed the preovulatory follicle under low concentrations of progesterone and in another treatment under high concentrations of progesterone. Treatments were achieved by administration of prostaglandin (PG) F2 $\alpha$ concurrent with the initiation of the Ovsynch protocol to regress the pre-existing CL on day 7 of the estrous cycle. By doing that, the authors created two treatments, one in which the pre-ovulatory follicle developed only with the newly formed CL (low progesterone) and another treatment in which the pre-ovulatory follicle developed with both, the pre-existing CL and the newly formed CL (high progesterone). Oocytes-embryos were collected by flushing the uteri of cows on day 7 after AI. A total of 81 oocytes-embryos were collected from 168 cows flushed. Fertilization was similar between treatments, but embryo quality was markedly depressed in cows in the low progesterone treatment (Table 1). Similar depression in embryo quality has been observed when lactating dairy cows subjected to superstimulatory treatments initiated the follicle stimulating hormone (FSH) treatment under low concentration of progesterone in early metestrus (Rivera et al., 2011). Interestingly, in the embryo donor experiment, supplementing progesterone during early metestrus with two intravaginal inserts reestablished concentrations of progesterone similar to those observed in cows in which the FSH started in early diestrus and rescued embryo quality (Rivera et al., 2011).

Table 1. Effect of concentration of progesterone during follicle development on embryo quality in lactating dairy cows $^{1}$.

\begin{tabular}{lccc}
\hline & \multicolumn{2}{c}{ Treatment $^{2}$} & P-value \\
\cline { 2 - 4 } Item & Low progesterone & High progesterone & 0.43 \\
\hline Fertilization, \% (n/n) & $78.8(26 / 33)$ & $77.1(37 / 48)$ & 0.01 \\
Mean grade quality, 1 to 4 & 2.4 & 1.5 & 0.01 \\
Grade 1, \% (n/n) & $34.6(9 / 26)$ & $67.6(25 / 37)$ & 0.29 \\
Grade 2, \% (n/n) & $26.9(7 / 26)$ & $18.9(7 / 37)$ & 0.02 \\
Grade 1 and 2, \% (n/n) & $61.5(16 / 26)$ & $86.5(32 / 37)$ & 0.01 \\
Grade 4, \% (n/n) & $34.6(9 / 26)$ & $8.1(3 / 37)$ &
\end{tabular}

${ }^{1}$ Data from Wiltbank et al. (2011). ${ }^{2}$ Cows were synchronized to start the Ovsynch timed AI protocol (GnRH, 7 days PGF2 $\alpha, 56 \mathrm{~h} \mathrm{GnRH}, 16 \mathrm{~h} \mathrm{AI}$ ) starting on day 7 of the estrous cycle. Low progesterone cows received an injection of PGF2 $\alpha 1$ day after initiating the Ovsynch timed AI protocol to regress the pre-existing CL, whereas high progesterone cows received no further hormonal treatment.

It is interesting that the negative effects of developing the ovulatory follicle under low concentrations of progesterone are not limited to reduced embryo quality. Anovular cows and those estrous cyclic initiating the timed AI protocol under low concentrations of progesterone have increased risk of pregnancy loss (Bisinotto et al., 2010). It is well established that progesterone in the preceding estrous cycle influences endometrial function in the subsequent cycle (Shaham-Albalancy et al., 1997, 2001). Cows that 
develop the ovulatory follicle under low concentrations of progesterone have an earlier upregulation of endometrial expression of estrogen receptor- $\alpha$ protein in the postovulatory period and produce more PGF $2 \alpha$ following an oxytocin challenge than cows that develop the ovulatory follicle under high concentrations of progesterone (Cerri et al., 2011a). In fact, these cows are more likely to suffer from short luteal phases (Cerri et al., 2011a), which is devastating to maintenance of pregnancy in cattle.

Although early embryo quality is compromised in anovular cows, many still present an elongated conceptus by day 15 of gestation. Nevertheless, conceptuses from anovular cows have marked changes in transcriptome indicating molecular changes that can compromise subsequent survival and explain the increased pregnancy loss later in gestation. Ribeiro et al. (2016c) identified 500 transcripts differently expressed between anovular and estrous cyclic lactating Holstein cows. Of those, 262 were upregulated and 238 were downregulated in anovular cows. Many of those genes were related to the process of transitioning from a tubular to a filamentous conceptus in dairy cattle (Ribeiro et al., 2016a). Functional analysis of transcriptome data evaluated by Ribeiro et al. (2016c) observed that apoptosis, 14-3-3 signaling pathway, and autophagy were predicted to be increased in conceptus from anovular compared with those from estrous cyclic cows. These data suggest that conceptuses that survive to day 15 of gestation have altered molecular signatures that might favor mechanisms of cell death.

It is important to emphasize that one cannot ignore that anovulation is linked to numerous events that take place in early lactation such as excessive negative nutrient balance and diseases. Catabolism induced by negative energy balance and associated peripartum diseases are known to affect reproduction in dairy cows and to predispose them to have extended periods of anovulation (Ribeiro et al., 2016a, b; Santos et al., 2009). Diseases of inflammatory nature such as those that affect the reproductive tract and the mammary gland have catastrophic links with fertility in dairy cows. Cows that develop diseases are more likely to remain anovular and both influence fertility in dairy cattle. In fact, disease in early lactation leave long-lasting imprinting marks in the molecular features of conceptus (Ribeiro et al., 2016b), which likely respond for some of the reduced P/AI observed in anovular cows.

\section{Identification of anovular cows and those that respond to progesterone supplementation}

As in most biological systems, there is likely an ideal concentration of each hormone that would likely maximize pregnancy in dairy cattle. For progesterone, this concentration or range of concentration remains unknown and likely varies with the stage of the reproductive cycle. Nevertheless, it is clear that anovular cows and those that develop the ovulatory follicle with low concentrations of progesterone have marked reductions in P/AI (Bisinotto et al., 2010; Wiltbank et al., 2012b, 2014).
One of the challenges with anovular cows is that absence of a CL following an ultrasonographic examination of the ovaries or a single measurement of progesterone concentration in blood plasma or serum are likely to inflate the prevalence of the problem. Cows in proestrus, estrus and metestrus usually will have either a small CL or no visible CL at all, and concentrations of progesterone will be low, typically below $1.0 \mathrm{ng} / \mathrm{ml}$. This is why most studies characterizing the prevalence of anovular cows use two sequential ultrasound examinations of the ovaries 7 to 14 days apart or two sequential measurements of progesterone concentrations in blood in the same interval (Santos et al., 2009). In most cases, this approach to diagnosing anovular cows is not practical under field conditions because of the labor involved, particularly in large farms.

One approach that has been used effectively is a single ultrasonographic examination of the ovaries at a strategic time, when low progesterone is known to depress fertility (Silva et al., 2007). In fact, a single ultrasound examination at the beginning of the synchronization protocol is capable of identifying not only most of the anovular cows, but also cohort of cows known to have low P/AI (Bisinotto et al., 2010, 2013). A similar method has been the norm of identification of low fertility cows in grazing farms in New Zealand and elsewhere (Rhodes et al., 2003). In fact, estrous cyclic cows that received the timed AI program initiated during proestrus, estrus, or metestrus supposedly ovulated the first wave follicle when inseminated and had P/AI that was similar to that observed in anovular cows (Bisinotto et al., 2010). The observation that the presence of $\mathrm{CL}$ and not estrous cyclic status has the greatest impact on $\mathrm{P} / \mathrm{AI}$ is critical considering that approximately $25 \%$ of the cows receiving the first AI postpartum (Santos et al., 2009) and 22 to $46 \%$ of those receiving resynchronized AI (Fricke et al., 2003; Silva et al., 2009) lack a CL when the synchronization protocol is initiated. Therefore, the use of a single ultrasonographic examination of the ovaries when the synchronization protocol is initiated is suggested as the method of choice to select cows for therapy with supplemental progesterone.

\section{Supplementation with progesterone}

The concentration of progesterone during diestrus in dairy cows is determined by the rates of luteal steroidogenesis and clearance from the circulation (Wiltbank et al., 2012a). Therefore, more extensive catabolism usually results in reduced concentrations of progesterone in blood. The same concept would apply when cows receive exogenous progesterone. Treatment of growing heifers with progesterone inserts usually result in changes in plasma concentrations much greater than those typically observed when the same insert is used in high-producing dairy cows (Macmillan et al., 1991; Cerri et al., 2009), which is typically attributed to the more extensive catabolism of steroids by the splanchnic tissues in cows of increased nutrient intake and hepatic metabolism. Thus, when the same delivery 
method is used in cows with distinct metabolic rates, it is not a surprise that concentrations of progesterone in plasma will greatly differ.

The fact that concentrations of progesterone vary with the type of cattle receiving a given intravaginal insert has major implications to designing supplementation systems because practitioners usually have available methods to deliver progesterone that are designed for a given type of cattle, but eventually use in all categories of cows and heifers in the farm. An example is the controlled internal drug-release system designed by Welch et al. (1984) as a vaginal device for use in sheep that became an alternative to the nylon sponges that were formerly used to deliver progesterone (Welch, 1984). This system later adapted to be used in cattle (Macmillan et al., 1990), but it was designed to be used in heifers to facilitate adoption of AI (Macmillan et al., 1991). Later, the same technology was adopted for use in lactating cows of moderate frame size and low genetic potential for production (Macmillan and Peterson, 1993). Use of the same delivery system in high-producing lactating dairy cows typically result in concentrations of progesterone in plasma that are only 20 to $30 \%$ of those observed in growing heifers or small-frame low producing cows (Cerri et al., 2009).

\section{Plasma concentrations during use of intravaginal inserts}

For the subsequent discussion, the example of the controlled internal drug-release (CIDR) insert will be used because of familiarity with the literature, although the information herein would likely apply to any intravaginal insert that releases 80 to $90 \mathrm{mg}$ of progesterone daily.

The original CIDR insert developed for cattle that still is marketed in many countries contains $1.9 \mathrm{~g}$ of progesterone. When used in ovariectomized heifers, it resulted in progesterone concentrations of $5.6 \mathrm{ng} / \mathrm{ml}$ for a period of 12 days, and the concentrations ranged from $8.7 \mathrm{ng} / \mathrm{ml}$ in the first hours after placement of the device in the vagina to $2.5 \mathrm{ng} / \mathrm{ml}$ at device removal on day 12 (Macmillan et al., 1991). These are typical concentrations of heifers in early to mid diestrus and more than enough to block estrus, LH surge and ovulation. In fact, when applied to intact heifers in diestrus, the concentrations of progesterone increased 5 to $6 \mathrm{ng} / \mathrm{ml}$ within the first $24 \mathrm{~h}$ of treatment (Macmillan et al., 1991). On the other hand, the same insert used in dry grazing New Zealand cows that had the CL regressed by PGF $2 \alpha$ resulted in a mean concentration of progesterone of $2.8 \mathrm{ng} / \mathrm{ml}$ for a period of 10 days (McMillan et al., 1991). Concentration was highest on the day of device insertion $(4.1 \mathrm{ng} / \mathrm{ml})$ and slowly declined to $1.9 \mathrm{ng} / \mathrm{ml}$ after 10 days of use. It is known from in vitro and in vivo drug release assessments that the CIDR insert releases on average approximately $89 \mathrm{mg}$ of progesterone daily (Rathbone et al., 2001, 2002) and the release is dependent primarily on the surface area of the device in contact with the mucosa of the vagina. However, it is unlikely that the delivery system is stable and not variable throughout the treatment period. In fact, although concentrations of progesterone in high-producing lactating dairy cows average $1 \mathrm{ng} / \mathrm{ml}$ when $89 \mathrm{mg}$ of progesterone is delivered daily by the intravaginal insert, considerable cow to cow variability exist (Cerri et al., 2009), either because of the pharmacokinetics vary among cows or because the delivery is not constant in all inserts. Likely both occur and explain the variability in blood progesterone responses when lactating dairy cows are treated with intravaginal inserts.

The re-engineered CIDR that is marketed in the United States and other countries contains $1.38 \mathrm{~g}$ of progesterone, but it is supposed to release the same amount daily as the original device containing $1.9 \mathrm{~g}$ (Rathbone et al., 2001; 2002). Cerri et al. (2009) evaluated the concentrations of progesterone when estrous cyclic high-producing Holstein lactating cows received a new (1.38 g of progesterone) or a 7-day used CIDR insert after regressing the CL. The authors showed that a device releasing $89 \mathrm{mg}$ of progesterone daily (Rathbone et al., 2001, 2002) increased concentrations in plasma by approximately 0.8 to 1.0 $\mathrm{ng} / \mathrm{ml}$ (Cerri et al., 2009). Concentrations increased in the first $15 \mathrm{~min}$ and reached a plateau by $90 \mathrm{~min}$ after insertion of the device. Similar to the findings of Macmillan et al. (1991), concentrations declined over the course of use of the device, but in the lactating Holstein cow, they dropped to 0.5 to $0.7 \mathrm{ng} / \mathrm{ml}$ after 7 days of use. These concentrations of progesterone in dairy cows are sufficient to block estrus and the LH surge and ovulation, but not ideal to improve fertility when the goal is to supplement progesterone (Bisinotto and Santos, 2012; Bisinotto et al., 2015a). This probably explains why previous studies in which a single CIDR was incorporated into timed AI programs demonstrated inconsistent responses in anovular cows (Bisinotto and Santos, 2012). The incremental progesterone from a single insert is likely insufficient to optimize follicle or oocyte maturation during the final stages of development before AI, or even to prime the endometrium for proper post-insemination function during conceptus development and maintenance of pregnancy.

Because release of progesterone from intravaginal devices is dependent primarily on the surface area in contact with the vaginal mucosa (Rathbone et al., 2001, 2002), it is not a surprise that addition of multiple devices increases progesterone in plasma in a parallel manner to the number of inserts used (Macmillan et al., 1991; Lima et al., 2009). This is important because in many countries approval of new devices is costly, but opportunities exist for extra-label use of current devices to target individuals that might require daily doses of progesterone of at least 180 to $200 \mathrm{mg}$ such as high-producing anovular dairy cows.

\section{Incorporation of supplemental progesterone in synchronization programs}

Programs for synchronization of ovulation and timed AI have been implemented worldwide as a management tool for the systematic control of reproduction in dairy herds. Timed AI programs allow for submission of all eligible cows to insemination with 
satisfactory $\mathrm{P} / \mathrm{AI}$, which typically improves pregnancy rates especially when detection of estrus is inefficient (Tenhagen et al., 2004) or when replacing breeding by natural service (Lima et al., 2012). Fertility of estrous cyclic and anovular lactating dairy cows induced to ovulate the first-wave dominant follicle is usually compromised (Bisinotto et al., 2010). Our work has clearly demonstrated that first-wave follicles that develop concurrently with the CL and, therefore, under low concentrations of progesterone result in alterations in the follicular fluid composition (Cerri et al., 2011a), alterations in endometrial function (Cerri et al., 2011a), reduced embryo quality (Rivera et al., 2011; Wiltbank et al., 2011), and compromised P/AI (Bisinotto et al., 2010). More importantly, our work has shown that progesteron is likely to mediated these changes in reproductive responses of cows ovulating the dominant follicle of the first follicular wave (Bisinotto et al., 2013). In fact, reduction in progesterone concentraiton during development of the second wave follicle markedly reduced embryo quality in single ovulating dairy cows (Table 1; Wiltbank et al., 2011).

Timed AI programs provide a unique platform for the manipulation of the ovulatory follicle in order to improve P/AI in dairy cows. One of these opportunities is the supplementation of progesterone to cows that are identified as being anovular or those in which the stage of the cycle results in low concentration of progesterone during the final phase of follicle development. Because lack of a CL when the timed AI protocol is initiated is predictive of low fertility, it then becomes logical that identification of cows without CL would be one of the targeted populations to receive supplemental progesterone (Bisinotto et al., 2013, 2015a).

It is important to emphasize that synchronization programs based on the use of estrogens such as those with estradiol benzoate do require a source of exogenous progesterone (Baruselli et al., 2004), otherwise cows without a CL when estrogens are administered or those that regress the CL after the treatment with estrogens will not have a properly synchronized estrus or ovulation.

\section{Supplemental progesterone during the timed AI protocol according to presence of $C L$}

Numerous studies have evaluated the impact of supplementing exogenous progesterone during timed AI protocols on fertility of dairy cows. Bisinotto et al. (2013, 2015a) evaluated the effect of supplementing progesterone in GnRH-PGF $2 \alpha$ based synchronization protocols. The authors showed that increasing progesterone in blood above $2.0 \mathrm{ng} / \mathrm{ml}$ with use of two intravaginal inserts restored fertility in cows without CL similar to that of cows in diestrus. The data of Bisinotto et al. (2015a) suggested that a minimum of approximately $2.0 \mathrm{ng} / \mathrm{ml}$ was needed during the development of the ovulatory follicle to optimize fertility in high-producing dairy cows (Fig. 1). Such response likely explains the lack of benefit of a single intravaginal insert that results in 0.8 to $1.0 \mathrm{ng} / \mathrm{ml}$ in cows without a CL (Bisinotto and Santos, 2012). In fact, when progesterone was supplemented to cows without a
CL with the use of 2 intravaginal inserts (Bisinotto et al., 2013, 2015a), to supply approximately $180 \mathrm{mg}$ of progesterone released per day (Rathbone et al., 2001, 2002), then the P/AI was similar to that of cows in diestrus when the timed AI protocol was initiated (Table 2 ). The increments observed were of approximately 10 percentage units in P/AI (Bisinotto et al., 2013, 2015a; Lima et al., 2009).

Most experiments evaluating the use of supplemental progesterone were not necessarily designed considering that the intravaginal device might not supply the amounts needed to improve fertility in dairy cow. Because of that, it is then not surprising that the responses to supplemental progesterone during synchronization programs have been equivocal (Bisinotto and Santos, 2012). The inconsistency in results led us to conduct a systematic review of the literature with the objective to evaluate whether progesterone supplementation using a single intravaginal insert during timed AI programs benefit fertility in lactating dairy cows (Bisinotto et al., 2015b). A total of 25 randomized controlled experiments including 16,683 dairy cows, half supplemented and half untreated controls were included in the metaanalysis. A portion of the studies, 21 experiments including 13,762 cows $(82.5 \%$ of the all cows) had information whether they were in diestrus or did not have a CL when the timed AI protocol was initiated. Additional information collected included detection or no detection of the estrus during the timed AI protocol and if cows had or did not have the estrous cycle presynchronized before enrollment in the timed AI program. The meta-analysis revealed that progesterone supplementation increased $\mathrm{P} / \mathrm{AI}$ on day 32 and 60 after insemination by 8 (relative risk $[\mathrm{RR}]=1.08 ; 95 \%$ confidence interval $[\mathrm{CI}]=1.03$ to 1.17$)$ and $10 \%(\mathrm{RR}=$ $1.10 ; 95 \% \mathrm{CI}=1.03$ to 1.17 ), respectively. Interestingly, the benefit of treating cows with progesterone during the timed AI protocols was greater in cows without CL (P/AI on day $60: \mathrm{RR}=1.18 ; 95 \% \mathrm{CI}=1.07$ to 1.30$)$ than those in diestrus $(\mathrm{RR}=1.06 ; 95 \% \mathrm{CI}=0.99$ to 1.12). Also, progesterone supplementation benefited $\mathrm{P} / \mathrm{AI}$ only when all cows were subjected to timed AI. When detection of estrus was performed throughout the synchronization protocol, and cows could be inseminated if observed in estrus, then progesterone did not increase P/AI. Collectively, these results clearly demonstrate that cows without $\mathrm{CL}$ benefit from progesterone supplementation, but delivering 80 to 90 $\mathrm{mg}$ of progesterone/day to high-producing Holstein cows is not ideal. For instance, the $16 \%$ increase in RR of P/AI on day 60 after insemination when anovular cows received supplemental progesterone with a single insert to deliver $90 \mathrm{mg} /$ day translated into an increment of 6.0 percentage units (from 27.3 to $33.3 \%$ ) in $\mathrm{P} / \mathrm{AI}$ (Bisinotto et al., 2015b), still less than the value typically observed when anovular cows received two inserts to deliver twice the progesterone (Table 2). The results of the meta-analysis also demonstrate that one of the benefits of progesterone supplementation is to better synchronize estrus/ovulation in these programs because detection of estrus and insemination during the protocol abolished the positive effects of supplementation on fertility. 


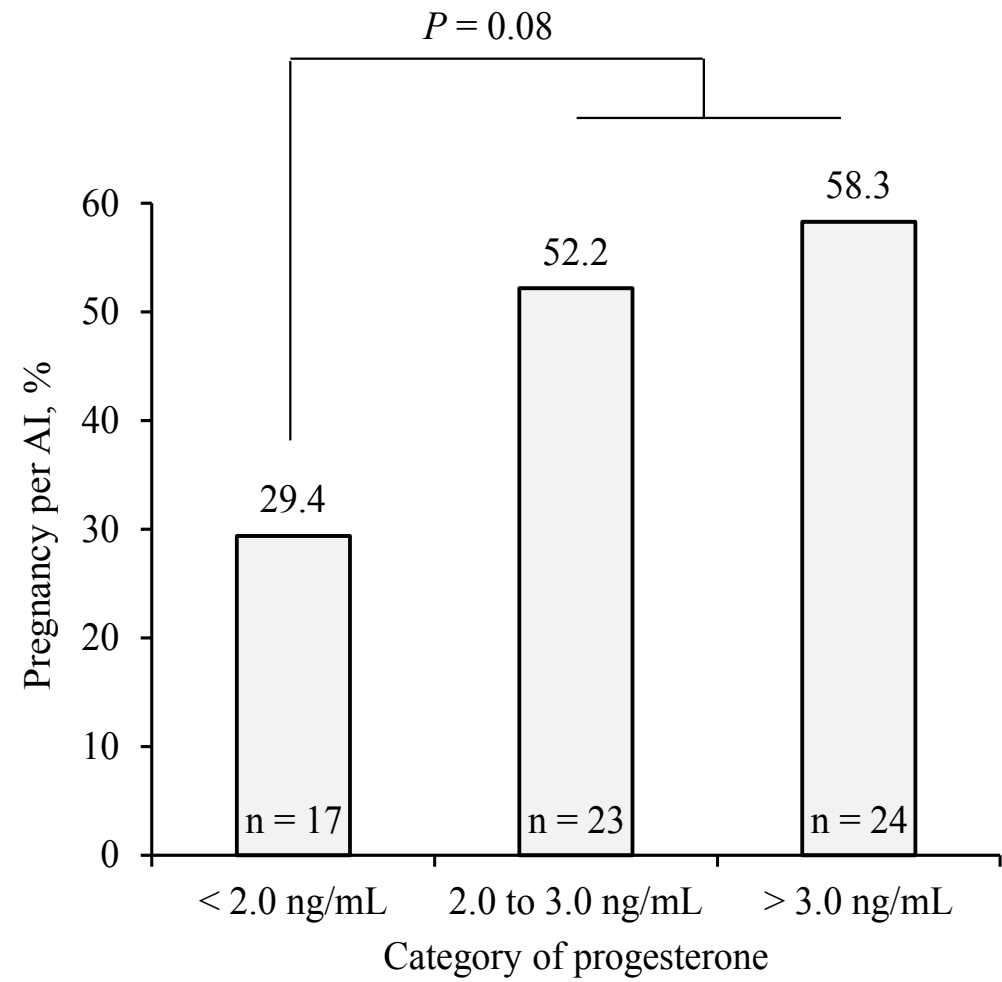

Figure 1. Pregnancy per AI on day 32 after insemination based on the concentrations of progesterone during follicle growth in cows receiving 2 intravaginal inserts containing progesterone during follicle growth in the Ovsynch protocol. Cows were categorized as having progesterone $<2.0 \mathrm{ng} / \mathrm{mL}(1.66 \pm 0.32 \mathrm{ng} / \mathrm{ml})$, from 2.0 to $3.0 \mathrm{ng} / \mathrm{ml}$ $(2.53 \pm 0.26 \mathrm{ng} / \mathrm{ml})$, or $>3.0 \mathrm{ng} / \mathrm{ml}(3.97 \pm 0.89 \mathrm{ng} / \mathrm{ml})$ between the day of the first $\mathrm{GnRH}$ and that of the PGF2 $\alpha$. Data from Bisinotto et al. (2015a).

Table 2. Effect of presence of corpus luteum (CL) and progesterone supplementation for cows without CL at the initiation of the timed AI protocol on fertility responses.

\begin{tabular}{ccc} 
& Treatment $^{1}$ & \\
\hline No CL control & $\begin{array}{c}\text { No CL and } \\
\text { progesterone }\end{array}$ & Diestrus \\
\hline$\%(n)$. &
\end{tabular}

Estrus at AI

Bisinotto et al. (2013)

Bisinotto et al. (2015a)

Mean estrus at AI

Pregnant day 60

Bisinotto et al. (2013)

Bisinotto et al. (2015a)

Lima et al. (2009)

Mean pregnancy day 60

Pregnancy loss

Bisinotto et al. (2013)

Bisinotto et al. (2015a)

Lima et al. (2009)

Mean pregnancy loss

$34.2(234)$
$35.8(652)$
35.4

$28.6(234)$

$28.9(642)$

$23.0(87)$

28.3

$6.9(72)$

8.5 (208)

16.7 (24)
36.2 (218)

$39.6(635)$

38.7

43.7 (215)

$32.9(85)$

38.4

$11.4(260)$

$9.7(31)$

9.7
$35.0(946)$

30.6 (640)

33.2

47.3 (941)

33.9 (633)

35,9 (334)

40.9

8.4 (131)

6.4

${ }^{1}$ All cows were subjected to the 5-days timed AI protocol (Bisinotto et al., 2013), Ovsynch-56 protocol (Bisinotto et al., 2015a) or Heatsynch protocol (Lima et al., 2009). No CL control = cows without a CL on the day of the first $\mathrm{GnRH}$ that received no supplemental progesterone; No CL progesterone $=$ cows without a CL on the day of the first $\mathrm{GnRH}$ that received two intravaginal inserts containing each $1.38 \mathrm{~g}$ of progesterone; Diestrus = cows with CL on the day of the first GnRH of the timed AI protocol. 


\section{Conclusion}

Delayed resumption of ovulation beyond 60 days postpartum affects a large proportion of dairy cows. Development of the ovulatory follicle under low concentrations of progesterone is the hallmark in anovular cows when subjected to synchronized inseminations. Suboptimal concentration of progesterone during follicle growth is one of the impediments for adequate fertility and markedly decreases P/AI in cows subjected to synchronization of estrus and ovulation. The compromised fertility observed in anovular cows is attributed to changes in the follicle/oocyte which carryover to the developing embryo, but also legacy effects on the conceptus and uterus that influence receptivity to pregnancy and maintenance of the CL. Supplementing progesterone to high-producing dairy cows has not always improved fertility in a consistent manner. In many cases, the inability of progesterone to improve $\mathrm{P} / \mathrm{AI}$ is attributed to the delivery method that has not always been ideal for the type of cow under question. When sufficient progesterone is supplied to anovular cows and those without a CL at the initiation of the timed AI protocol, then fertility is restored similar to that of cows in diestrus. Based on the limited data available, it is suggested that a minimum of $2.0 \mathrm{ng} / \mathrm{ml}$ is needed during follicle development to improve fertility in dairy cows. Reaching such concentrations with supplemental progesterone increased $\mathrm{P} / \mathrm{AI}$ by approximately 10 percentage units, equalizing that of cows in diestrus. On the other hand, when supplemental progesterone increases plasma concentrations by only 0.8 to 1.0 $\mathrm{ng} / \mathrm{ml}$ then, although benefits were also observed, they usually ranged from 3 to 5 percentage units increment in $\mathrm{P} / \mathrm{AI}$, which is not sufficient to reach the values of $\mathrm{P} / \mathrm{AI}$ observed in cows in diestrus.

\section{Acknowledgments}

Funding for experiments conducted by the authors and presented in this review was provided by grants from the Southeast Milk Inc. Checkoff Program (Belleview, FL) and from the National Institute of Food and Agriculture, United States Department of Agriculture award number 2015-67015-23313.

\section{References}

Alexopoulos NI, Vajta G, Maddox-Hyttel P, French AJ, Trounson AO. 2005. Stereomicroscopic and histological examination of bovine embryos following extended in vitro culture. Reprod Fertil Dev, 17:799808.

Bazer FW, Burghardt RC, Johnson GA, Spencer TE, Wu G. 2008. Interferons and progesterone for establishment and maintenance of pregnancy: interactions among novel cell signaling pathways. Reprod Biol, 8:179-211.

Badinga L, Driancourt MA, Savio JD, Wolfenson D, Drost M, De La Sota RL, Thatcher WW. 1992. Endocrine and ovarian responses associated with the first-wave dominant follicle in cattle. Biol Reprod, 47:871-883.

Baruselli PS, Reis EL, Marques MO, Nasser LF, Bó GA. 2004. The use of hormonal treatments to improve reproductive performance of anestrous beef cattle in tropical climates. Anim Reprod Sci, 82-83:479-486.

Bisinotto RS, Chebel RC, Santos JEP. 2010. Follicular wave of the ovulatory follicle and not cyclic status influences fertility of dairy cows. J Dairy Sci, 93:3578-3587.

Bisinotto RS, Santos JEP. 2012. The use of endocrine treatments to improve pregnancy rates in cattle. Reprod Fertil Dev, 24:258-266.

Bisinotto RS, Ribeiro ES, Lima FS, Martinez N, Greco LF, Barbosa LF, Bueno PP, Scagion LF, Thatcher WW, Santos JEP. 2013. Targeted progesterone supplementation improves fertility in lactating dairy cows without a corpus luteum at the initiation of the timed artificial insemination protocol. $J$ Dairy Sci, 96:2214-2225.

Bisinotto RS, Ribeiro ES, Santos JEP. 2014. Synchronisation of ovulation for management of reproduction in dairy cows. Animal Suppl, 1:151-159.

Bisinotto RS, Castro LO, Pansani MB, Narciso CD, Martinez N, Sinedino LDP, Pinto TLC, Van de Burgwal NS, Bosman HM, Surjus RS, Thatcher WW, Santos JEP. 2015a. Progesterone supplementation to lactating dairy cows without corpus luteum at the initiation of the Ovsynch protocol. J Dairy Sci, 98: 2515-2528.

Bisinotto RS, Lean IJ, Thatcher WW, Santos JEP. 2015b. Meta-analysis of progesterone supplementation during timed AI programs in dairy cows. J Dairy Sci, 98:2472-2487.

Brandão DO, Maddox-Hyttel P, Lovendahl P, Rumpf R, Stringfellow D, Callesen H. 2004. Post hatching development: a novel system for extended in vitro culture of bovine embryos. Biol Reprod, 71:20482055.

Cerri RL, Rutigliano HM, Bruno RG, Santos JEP. 2009. Progesterone concentration, follicular development and induction of cyclicity in dairy cows receiving intravaginal progesterone inserts. Anim Reprod Sci, 110:56-70.

Cerri RL, Chebel RC, Rivera F, Narciso CD, Oliveira RA, Amstalden M, Baez-Sandoval GM, Oliveira LJ, Thatcher WW, Santos JEP. 2011a. Concentration of progesterone during the development of the ovulatory follicle: II. Ovarian and uterine responses. J Dairy Sci, 94:3352-3365.

Cerri RL, Chebel RC, Rivera F, Narciso CD, Oliveira RA, Thatcher WW, Santos JEP. 2011 b. Concentration of progesterone during the development of the ovulatory follicle: I. Ovarian and embryonic responses. J Dairy Sci 94:3342-3351.

Clarke IJ 1995. Evidence that the switch from negative to positive feedback at the level of the pituitary gland is an important timing event for the onset of the preovulatory surge in LH in the ewe. $J$ Endocrinol, 145:271-282.

Clarke IJ, Pompolo S. 2005. Synthesis and secretion of GnRH. Anim Reprod Sci, 88:29-55. 
Conley AJ, Ford SP. 1987. Effect of prostaglandin F2 alpha-induced luteolysis on in vivo and in vitro progesterone production by individual placentomes of cows. J Anim Sci, 65:500-507.

Corner G, Allen W. 1929. Physiology of the corpus luteum. II. Production of a special uterine reaction (progestational proliferation) by extracts of the corpus luteum. Am J Physiol, 88:326-399.

Endo N, Nagai K, Tanaka T, Kamomae H. 2012. Comparison between lactating and non-lactating dairy cows on follicular growth and corpus luteum development, and endocrine patterns of ovarian steroids and luteinizing hormone in the estrous cycles. Anim Reprod Sci, 134:112-118.

Folman Y, Rosenberg M, Herz Z, Davidson M. 1973. The relationship between plasma progesterone concentration and conception in post-partum dairy cows maintained on two levels of nutrition. J Reprod Fertil, 34:267-278.

Fraenkel L, Cohn F. 1901. Experimentelle untersuchungen des corpus luteum auf die insertion des eies (Theorie von Born). Anat Anz, 20:294-300.

Fricke PM, Caraviello DZ, Weigel KA, Welle ML. 2003. Fertility of dairy cows after resynchronization of ovulation at three intervals following first timed insemination. J Dairy Sci, 86:3941-3950.

Goodman RL, Bittman EL, Foster DL, Karsch FJ. 1982. Alterations in the control of luteinizing hormone pulse frequency underlie the seasonal variation in estradiol negative feedback in the ewe. Biol Reprod, 27:580-589.

Goodman RL, Karsch FJ. 1980. Pulsatile secretion of luteinizing hormone: differential suppression by ovarian steroids. Endocrinology, 107:1286-1290.

Herbison AE, Skinner DC, Robinson JE, King IS. 1996. Androgen receptor-immunoreactive cells in ram hypothalamus: distribution and co-localization patterns with gonadotropin-releasing hormone, somatostatin and tyrosine hydroxylase. Neuroendocrinology, 63:120-131. Lane EA, Sweeney T, Ryan M, Roche JF, Crowe MA. 2009. Relationship between serum gonadotropins and pituitary immunoreactive gonadotropins and steroid receptors during the first FSH increase of the estrous cycle and following steroid treatment in heifers. Anim Reprod Sci, 112:66-82.

Lima FS, Bisinotto RS, Ribeiro ES, Ayres H, Greco LF, Galvão KN, Risco CA, Thatcher WW, Santos JEP. 2012. Effect of one or three timed artificial inseminations before natural service on reproductive performance of lactating dairy cows not observed for detection of estrus. Theriogenology, 77:1918-1927.

Lima JR, Rivera FA, Narciso CD, Oliveira R, Chebel RC, Santos JEP. 2009. Effect of increasing amounts of supplemental progesterone in a timed artificial insemination protocol on fertility of lactating dairy cows. J Dairy Sci, 92:5436-5446.

Lonergan PAD, Forde N, Spencer T. 2016. Role of progesterone in embryo development in cattle. Reprod Fertil Dev, 28: 66-74.

Macmillan KL, Washburn SP, Henderson HV, Petch SF. 1990. Effects of varying the progesterone content of the CIDR intravaginal device and multiple CIDR treatments on plasma hormone concentrations and residual hormone content. Proc NZ Soc Anim Prod, 50:471-472.

Macmillan KL, Taufa VK, Barnes DR, Day AM. 1991. Plasma progesterone concentrations in heifers and cows treated with a new intravaginal device. Anim Reprod Sci, 26:25-40.

Macmillan KL, Peterson AJ. 1993. A new intravaginal progesterone releasing device for cattle (CIDR-B) for oestrous synchronization, increasing pregnancy rates and the treatment of post-partum anoestrus. Anim Reprod Sci, 33:1-25.

Magnus V. 1901. Ovariets betydning for svangerskabet med saerligt hensyntil corpus luteum. No Mag Laegevidensk, 62:1138-1142.

Mason NR, Savard K. 1964. Conversion of cholesterol to progesterone by corpus luteum slices. Endocrinology, 75:215-221.

Monteiro Jr. PLJ, Ribeiro ES, Maciel RP, Dias ALG, Solé Jr. E, Lima FS, Bisinotto RS, Thatcher WW, Sartori R, Santos JEP. 2014. Effects of supplemental progesterone after AI on expression of interferon-stimulated genes and fertility in dairy cows. $J$ Dairy Sci, 97:4907-4921.

Monteiro Jr. PLJ, Nascimento AB, Pontes GCS, Fernandes GO, Melo LF, Wiltbank MC, Sartori R. 2015. Progesterone supplementation after ovulation: effects on corpus luteum function and on fertility of dairy cows subjected to AI or ET. Theriogenology, 84:1215-1224.

Nation DP, Burke CR, Parton G, Stevenson R, Macmillan KL. 2000. Hormonal and ovarian responses to a 5-day progesterone treatment in anoestrous dairy cows in the third week post-partum. Anim Reprod Sci, 63:13-25.

Rathbone MJ, JE Kinder, K Fike, F Kojima, D Clopton, CR. Ogle, and CR Bunt. 2001. Recent advances in bovine reproductive endocrinology and physiology and their impact on drug delivery system design for the control of the estrous cycle in cattle. $A d v$ Drug Deliv Rev, 50:277-320.

Rathbone MJ, Bunt CR, Ogle CR, Burggraaf S, Macmillan KL, Burke CR, Pickering KL. 2002. Reengineering of a commercially available bovine intravaginal insert (CIDR insert) containing progesterone. J Control Release, 85:105-115.

Rhodes FM, McDougall S, Burke CR, Verkerk GA, Macmillan KL. 2003. Invited review: Treatment of cows with an extended postpartum anestrous interval. $J$ Dairy Sci, 86:1876-1894.

Ribeiro ES, Greco LF, Bisinotto RS, Lima FS, Thatcher WW, Santos JEP. 2016a. Biology of preimplantation conceptus at the onset of elongation in dairy cows. Biol Reprod, 94:97, 1-18.

Ribeiro ES, Gomes G, Greco LF, Cerri RLA, VieiraNeto A, Monteiro Jr. PLJ, Lima FS, Bisinotto RS, Thatcher WW, Santos JEP. 2016b. Carryover impact of postpartum inflammatory diseases on developmental biology and fertility in lactating dairy cows. J Dairy Sci, 99:2201-2220.

Ribeiro ES, Monteiro APA, Bisinotto RS, Lima FS, Greco LF, Ealy AD, Thatcher WW, Santos JEP. 
2016c. Conceptus development and transcriptome at preimplantation stages in lactating dairy cows of distinct genetic groups and estrous cyclic statuses. J Dairy Sci, 99: 4761-4777.

Rivera FA, Mendonça LG, Lopes Jr. G, Santos JEP, Perez RV, Amstalden M, Correa-Calderón A Chebel RC. 2011. Reduced progesterone concentration during growth of the first follicular wave affects embryo quality but has no effect on embryo survival post transfer in lactating dairy cows. Reproduction, 141:333342.

Santos JEP, Thatcher WW, Chebel RC, Cerri RLA, Galvão KN. 2004. The effect of embryonic death rates in cattle on the efficacy of estrus synchronization programs. Anim Reprod Sci, 82/83:513-535.

Santos JEP, Rutigliano HM, Sá Filho MF. 2009. Risk factors for resumption of postpartum estrous cycles and embryonic survival in lactating dairy cows. Anim Reprod Sci, 110:207-221.

Santos JEP, Bisinotto RS, Ribeiro ES. 2016. Mechanisms underlying reduced fertility in anovular dairy cows. Theriogenology, 86:254-262.

Schoenemann HM, Humphrey WD, Crowder WE, Nett TM, and Reeves JJ. 1985. Pituitary luteinizing hormone-releasing hormone receptors in ovariectomized cows after challenge with ovarian steroids. Biol Reprod, 32:574-583.

Schumacher M, Guennoun R, Robert F, Carelli C, Gago N, Ghoumari A, Gonzalez Deniselle MC, Gonzalez SL, Ibanez C, Labombarda F, Coirini H, Baulieu EE, De Nicola AF. 2004. Local synthesis and dual actions of progesterone in the nervous system: neuroprotection and myelination. Growth Horm IGF Res, 14(suppl. A):18-33.

Shaham-Albalancy A, Nyska A, Kaim M, Rosemberg MM, Folman Y, Wolfenson D. 1997. Delayed effect of progesterone on endometrial morphology in dairy cows. Anim Reprod Sci, 48:159174.

Shaham-Albalancy A, Folman Y, Kaim M, Rosemberg M, Wolfenson D. 2001. Delayed effect of low progesterone concentrations on bovine uterine PGF(2alpha) secretion in the subsequent estrous cycle. Reproduction, 122:643-648.

Silva E, Sterry RA, Fricke PM. 2007. Assessment of a practical method for identifying anovular dairy cows synchronized for first postpartum timed artificial insemination. J Dairy Sci, 90:3255-3262.

Silva E, Sterry RA, Kolb D, Mathialagan N, McGrath MF, Ballam JM, Fricke PM. 2009. Effect of interval to resynchronization of ovulation on fertility of lactating Holstein cows when using transrectal ultrasonography or a pregnancy-associated glycoprotein enzyme-linked immunosorbent assay to diagnose pregnancy status. J Dairy Sci, 92:3643-3650.
Skinner DC, Caraty A, Allingham R. 2001. Unmasking the progesterone receptor in the preoptic area and hypothalamus of the ewe: no colocalization with gonadotropin-releasing neurons. Endocrinology, 142:573-579.

Tenhagen BA, Drillich M, Surholt R, Heuwieser W. 2004. Comparison of timed AI after synchronized ovulation to AI at estrus: reproductive and economic considerations. J Dairy Sci, 87:85-94.

Wagner WC, Strohbehn RE, Harris PA. 1972. ACTH, corticoids and luteal function in heifers. $J$ Anim Sci, 35:789-793.

Walsh RB, Kelton DF, Duffield TF, Leslie KE, Walton JS, LeBlanc SJ. 2007. Prevalence and risk factors for postpartum anovulatory condition in dairy cows. J Dairy Sci, 90:315-324.

Welch RAS. 1984. Development of CIDR dispensers for use in nulliparous ewes. Wellington, NZ: NZ Ministry of Agric \& Fish, Agric. Res. Div. Annual Report. 1983/84. . 58 pp.

Welch RAS, Andrews WD, Barnes DR, Bremner K, Harvey TG. 1984. CIDR dispensers for oestrus and ovulation control in sheep. In: Proceedings of the 10th International Congress on Animal Reproduction and Artificial Insemination, 1984, Urbana-Champaign. Urbana-Champaign, IL: Univ. of Illinois. vol. 3, p. 354.

Wiltbank MC, Gumen A, Sartori R. 2002. Physiological classification of anovulatory conditions in cattle. Theriogenology, 57:21-52.

Wiltbank MC, Lopez H, Sartori R, Sangsritavong S, Gümen A. 2006. Changes in reproductive physiology of lactating dairy cows due to elevated steroid metabolism. Theriogenology, 65:17-29.

Wiltbank MC, Carvalho PD, Keskin A, Sartori R, Hackbart KS, Meschiatti MA, Bastos MR, Guenther JN, Nascimento AB, Herlihy MM, Amundson MC, Souza AH. 2011. Effect of progesterone concentration during follicle development on subsequent ovulation, fertilization, and early embryo development in lactating dairy cows. Biol Reprod, 85:685. (abstract).

Wiltbank MC, Salih SM, Atli MO, Luo W, Bormann CL, Ottobre JS, Vezina CM, Mehta V, Diaz FJ, Tsai SJ, Sartori R. 2012a. Comparison of endocrine and cellular mechanisms regulating the corpus luteum of primates and ruminants. Anim Reprod, 9:242-259.

Wiltbank MC, Souza AH, Carvalho PD, Bender RW, Nascimento AB. 2012b. Improving fertility to timed artificial insemination by manipulation of circulating progesterone concentrations in lactating dairy cattle. Reprod Fertil Dev, 24:238-243.

Wiltbank MC, Souza AH, Carvalho PD, Cunha AP, Giordano JO, Fricke PM, Baez GM, Diskin MG. 2014. Physiological and practical effects of progesterone on reproduction in dairy cattle. Animal, 8(suppl. 1):70-81. 